\title{
VOLFO-PARKINSONO-VAITO SINDROMAS IR FENOMENAS
}

\author{
Viktorija Zieniūtè, Liveta Daleckytė \\ Lietuvos sveikatos mokslu universiteto Medicinos akademijos Medicinos fakultetas
}

\begin{abstract}
Raktažodžiai: Volfo-Parkinsono-Vaito sindromas, VolfoParkinsono-Vaito fenomenas, skilvelių preeksitacijos sindromas, elektrokardiografija, Ebšteino anomalija.
\end{abstract}

\section{Santrauka}

Remiantis naujausios mokslinès literatūros duomenimis, straipsnyje apžvelgiamas Volfo-Parkinsono-Vaito sindromo paplitimas, etiologiniai veiksniai, klinikinè reikšmė, diagnostikos ir gydymo galimybès. Atlikta sisteminė mokslinė apžvalga, ị kurią įtrauktos 25 Volfo-Parkinsono-Vaito sindromą ir (ar) fenomeną nagrinejjančios publikacijos, atrinktos PubMed ir UpToDate mokslinèse duomenų bazèse.

Volfo-Parkinsono-Vaito (VPV) sindromas yra ịimta širdies laidžiosios sistemos patologija - dažniausia kliniškai pasireiškiančios skilvelių preeksitacijos priežastis. VPV sindromui būdingas papildomas laidumo pluoštas (Kento pluoštas), tiesiogiai sujungiantis prieširdžių ir skilvelių laidžiąsias sistemas. Etiologija siejama su PRKAG2 geno mutacija. VPV sindromas gali sukelti gyvybei pavojingas būkles: prieširdžių virpejiimą ir staigią mirtį. Pagrindinis diagnostinis tyrimo metodas - elektrokardiografija (EKG), kurioje stebimi skilvelių preeksitacijos požymiai. Pagrindinis gydymo metodas - transkateterinè radiodažnuminè abliacija (TRA), indikuotina simptominiams arba asimptominiams pacientams, esant didelei staigios mirties rizikai.

\section{Ivadas}

L.Wolff, J.Parkinson ir P.White 1939 metais paskelbtame straipsnyje aprašè 11 pacientų, kuriems pasireiškè tachikardijos epizodai. Atliktoje EKG buvo stebimi Hiso pluošto kojytès blokadai būdingi pakitimai, esant sutrumpejjusiam PR intervalui. Vèliau ši aritmija buvo pavadinta Volfo-Parkinsono-Vaito (VPV) sindromu [1]. VPV sindromas - igimta širdies laidžiosios sistemos patologija, kuri lemia skilvelių preeksitaciją (skilvelių priešlaikinị sujaudinimą), komplikuotą širdies ritmo sutrikimais. VPV fenomenas EKG metu nustatomi klinikinių simptomų nesukeliantys skilvelių preeksitacijos požymiai [2]. Nepriklausomai nuo klinikinių simptomų pasireiškimo, jauniems pacientams gali išsivystyti gyvybei pavojingos būklès (prieširdžiu virpẻjimas, pereinantis ị skilvelių virpèjimą, staigi mirtis) [3].

Darbo tikslas - remiantis naujausios mokslinès literatūros duomenimis, apžvelgti Volfo-Parkinsono-Vaito sindromo paplitimą, etiologinius veiksnius, klinikinę reikšmę, diagnostikos ir gydymo galimybes.

\section{Tyrimo medžiaga ir metodai}

Naujausios mokslinès literatūros paieška buvo atlikta PubMed ir UpToDate mokslinėse duomenų bazèse. I sisteminę apžvalgą įtrauktos 25 mokslinès publikacijos, kuriose aprašomas Volfo-Parkinsono-Vaito sindromas ir (ar) fenomenas.

\section{Tyrimo rezultatai}

Epidemiologija. VPV sindromas yra dažniausia priežastis, lemianti skilvelių preeksitaciją ir pasireiškia $0,1-0,3$ proc. bendrosios populiacijos [4]. VPV fenomeno paplitimas bendrojoje populiacijoje nèra tiksliai žinomas dèl klinikinès simptomatikos nebuvimo. Pacientams, turintiems VPV fenomeną, klinikinio aritmijos atsiradimo rizika 12 ménesių laikotarpiu yra 1/100 [5]. VPV sindromas dažniausiai pasireiškia 20-24 metų amžiuje [6].

Etiologija. Tikimybè pirmos eilès giminaičiams paveldèti VPV sindromą yra 0,6 procento. Paveldimumas siejamas su PRKAG2 geno mutacija [7,8]. VPV sindromas ịprastai nesiejamas su gretutinėmis struktūrinèmis širdies patologijomis, tačiau remiantis A. Stasiak su kolegomis atlikto tyrimo rezultatais, 2008-2015 m. laikotarpiu iš 45 vaikų (amžiaus vidurkis 11 metų) 8,9 proc. buvo nustatytas struktūrinis širdies defektas [9]. Remiantis P. Torres atlikta studija, igimta triburio vožtuvo ir dešiniojo skilvelio patologija (Ebšteino anomalija) gali lemti skilvelių preeksitacijos išsivystymą [10].

Patofiziologija. Prieširdžiuose ir skilveliuose laidžiosios sistemos takai yra atskiri, o elektriniai impulsai iš skilvelių i prieširdžius patenka per atrioventrikulini mazgą (AVM) ir Hiso-Purkinje sistemą [11]. VPV sindromui būdingas papildomas laidumo pluoštas (Kento pluoštas), kuris tiesiogiai sujungia prieširdžių ir skilvelių laidžiąsias sistemas 
[12]. Kento pluoštu elektrinis impulsas tiesiogiai plinta iš prieširdžiu ị skilvelius, aplenkia AVM ir sukelia priešlaikini skilvelių sujaudinimą (preeksitaciją) [13].

Klinikinė reikšmė. VPV sindromas ar fenomenas gali sukelti gyvybei pavojingas būkles jauniems sveikiems pacientams [14]. Remiantis S. Kim ir bendraautorių atlikto klinikinio tyrimo rezultatais, dažniausiai gyvybei pavojingos būklès (prieširdžių virpèjimas, staigi mirtis) pasireiškia 14 metų amžiaus pacientams. Remiantis daugiaveiksmès analizès rezultatais, vyriška lytis, Ebšteino anomalija, prieširdžių virpèjimas, pokyčiai elektrofiziologinio tyrimo metu yra gyvybei pavojingų būklių rizikos veiksniai [3].

Klinika. Esant VPV fenomenui, EKG stebimi VPV sindromui būdingi pokyčiai, kurie dažniausiai simptomų nesukelia. Daugeliu atvejų VPV fenomenas diagnozuojamas pasireiškus kitiems širdies ritmo sutrikimams: prieširdžių virpèjimui, prieširdžių plazdèjimui, skilvelinei tachikardijai ir skilvelių virpéjimui [15]. VPV sindromas, kaip ir kitos tachiaritmijos, pasireiškia širdies ritmo sutrikimams būdingais simptomais: 1) jaučiamas širdies plakimas; 2)galvos svaigimas; 3) sinkopé; 4) krūtinès skausmas; 5) staigus širdies sustojimas [16].

Diagnostika. EKG - pagrindinis diagnostinis metodas, nustatant VPV fenomeną ir sindromą. EKG stebimi pokyčiai: trumpas PR intervalas $(\leq 120 \mathrm{~ms})$, ilgas QRS kompleksas (>120 ms), delta banga. Šiuos pokyčius sukelia išankstinis skilvelių sužadinimas dèl papildomo laidumo pluošto $[17,18]$. Nestebint skilvelių preeksitacijai būdingų pokyčių EKG, negalima teigti, kad papildomų laidumo takų širdyje nèra, nes kartais impulsai Kento pluoštu plinta tik retrogradiškai - impulsas iš skilvelių plinta ị prieširdžius, todèl nèra išankstinio skilvelių sujaudinimo [5]. Elektrofiziologinis tyrimas (EFT) daugeliu atvejų nèra būtinas VPV sindromo ar fenomeno diagnozei nustatyti [19]. Jauniems, sveikiems, gretutinių ligų neturintiems pacientams, kurių anamnezeje nèra širdies ritmo sutrikimų, nepriklausomai nuo EKG stebimų skilvelių preksitacijos požymių, EFT neindikuotinas [20]. Tokie pacientai yra stebimi pirminès sveikatos priežiūros specialisto ar kardiologo. Pacientams, kurių anamnezèje yra tachiaritmijos epizodų ar EKG nuolat stebimi skilvelių preeksitacijai būdingi požymiai, yra indikuotinas invazinis EFT, kuris gali būti tiek diagnostinis, tiek gydomasis [19]. EFT metu nustačius didelę staigios mirties riziką, atliekama TRA, sunaikinant papildomus laidumo takus [21].

Gydymas. Pacientams, turintiems asimptominị VPV fenomeną, skubus gydymas neindikuotinas. Esant didelei tachiaritmijos rizikai, profilaktiškai skiriami antiaritminiai vaistai [22]. Dèl didesnès aritmijos pasikartojimo rizikos, pacientai su VPV fenomenu ir tachiaritmijos epizodu anamnezèje, priešingai nei asimptominiai pacientai, turi būti gydomi [23]. Pagrindinis simptominių pacientų gydymas - TRA (alternatyva TRA - chirurginè abliacija) [24]. Esant intervencinio gydymo kontraindikacijų, pasirenkama farmakoterapija: 1) flekainidas ir propafenonas neturintiems struktūrinès širdies patologijos; 2) sotalolis ar dofetilidas, turintiems širdies struktūrinę patologiją [25].

\section{Išvados}

1. VPV sindromas - dažniausia priešlaikinio skilvelių sujaudinimo priežastis, kurios paplitimas bendrojoje populiacijoje $0,1-0,3$ proc., dažniausiai pasireiškiantis 20-24 metu amžiaus asmenims.

2. VPV sindromą ar fenomeną lemia ịgimti papildomi širdies laidžiosios sistemos takai (Kento pluoštas), kurių etiologija siejama su PRKAG2 geno mutacija.

3. VPV sindromas ar fenomenas gali sukelti gyvybei pavojingas būkles: prieširdžių virpejimą ir staigią mirtị.

4. Pagrindinis diagnostinis tyrimo metodas - EKG, kurioje stebimi skilvelių preeksitacijos požymiai. Esant indikacijų, gali būti atliekamas EFT. Pagrindinis gydymo metodas - TRA, indikuotina simptominiams arba asimptominiams pacientams, esant didelei staigios mirties rizikai.

\section{Literatūra}

1. Wolff L, Parkinson J, White PD. Bundle-branch block with short P-R interval in healthy young people prone to paroxysmal tachycardia. Ann Noninvasive Electrocardiol 2006;11(4):340-53. https://doi.org/10.1111/j.1542-474X.2006.00127.x

2. Castro RL, Alcantara Lima N, Costa Lino DO, Bannon SF. Concealed Wolff-Parkinson-White syndrome revealed by acute coronary syndrome. Ann Noninvasive Electrocardiol 2020;25(5). https://doi.org/10.1111/anec. 12735

3. Etheridge SP, Escudero CA, Blaufox AD, Law IH, DechertCrooks BE, Stephenson EA, et al. Life-threatening event risk in children with Wolff-Parkinson-White Syndrome. JACC Clin Electrophysiol 2018;4(4):433-44. https://doi.org/10.1016/j.jacep.2017.10.009

4. Sapra A, Albers J, Bhandari P, Davis D, Ranjit E. Wolff-Parkinson-White syndrome: a master of disguise. Cureus 2020;12(6). https://doi.org/10.7759/cureus.8672

5. Chhabra L, Goyal A, Benham MD. Wolff Parkinson White syndrome Stat Pearls. Stat Pearls Publishing 2020.

http://www.ncbi.nlm.nih.gov/pubmed/32119324

6. Lu CW, Wu MH, Chen HC, Kao FY, Huang SK. Epidemiological profile of Wolff-Parkinson-White syndrome in a general population younger than 50 years of age in an era of radiofrequency catheter ablation. Int J Cardiol 2014;174(3):530-4.

https://doi.org/10.1016/j.ijcard.2014.04.134

7. Miyamoto L. Molecular pathogenesis of familial Wolff-Parkinson-White syndrome. J Med Invest 2018;65(1.2): 1-8. https://doi.org/10.2152/jmi.65.1 
8. Porto AG, Brun F, Severini GM, Losurdo P, Fabris E, Taylor MRG, et al. Clinical spectrum of PRKAG2 syndrome. Circ Arrhythmia Electrophysiol 2016;9(1). https://doi.org/10.1161/CIRCEP.115.003121

9. Stasiak A, Niewiadomska-Jarosik K, Kędziora P. Clinical course and treatment of children and adolescents with the preexcitation syndrome - own studies. Dev period Med 2018;22(2):113-22. https:// pubmed.ncbi.nlm.nih.gov/30056397/

10. Torres PI. Wolff-Parkinson-White syndrome in Ebstein's anomaly. Arch Cardiol Mex 2007;77(2).

https://pubmed-ncbi-nlm-nih-gov.ezproxy.dbazes.1smuni. 1t/17972375/

11. Heaton J, Goyal A. Atrioventricular node Stat Pearls. Stat Pearls Publishing 2020. http://www.ncbi.nlm.nih.gov/pubmed/32491596

12. Bhattad PB, Brijmohan P, Resident B, Brijmohan Bhattad P, Jain V. Revisiting electrocardiographic Wolff-Parkinson-White Pattern. J Med Res 2020;6(4):114-6. https://doi.org/10.31254/jmr.2020.6401

13. Zachariah JP, Walsh EP, Triedman JK, Berul CI, Cecchin F, Alexander ME, et al. Multiple accessory pathways in the young: the impact of structural heart disease. Am Heart J 2013 Jan;165(1):87-92. https://doi.org/10.1016/j.ahj.2012.10.025

14. Kim SS, Knight BP. Long term risk of Wolff-Parkinson-White pattern and syndrome.Trends in Cardiovascular Medicine. Elsevier Inc 2017;27:260-8.

https://doi.org/10.1016/j.tcm.2016.12.001

15. Song C, Guo Y, Zheng X, Lu J, Fang X, Wang S, et al. Prognostic significance and risk of atrial fibrillation of Wolff-ParkinsonWhite syndrome in patients with hypertrophic cardiomyopathy. Am J Cardiol 2018;122(9):1546-50. https://doi.org/10.1016/j.amjcard.2018.07.021

16. Senst B, Zeltser R. Reentry arrhythmia StatPearls. StatPearls Publishing 2019.

http://www.ncbi.nlm.nih.gov/pubmed/30725774

17. Bhatia A, Sra J, Akhtar M. Preexcitation syndromes. Curr Probl Cardiol 2016;41(3):99-137. https://doi.org/10.1016/j.cpcardiol.2015.11.002

18. Brugada J, Katritsis DG, Arbelo E, Arribas F, Bax JJ, Blomstrom-Lundqvist C, et al. 2019 ESC guidelines for themanagement of patients with supraventricular tachycardia. Eur Heart J 2020;41(5):655-720. https://doi.org/10.1093/eurheartj/ehz467

19. Cohen MI, Triedman JK, Cannon BC, Davis AM, Drago F, Janousek J, et al. PACES/HRS expert consensus statement on the management of the asymptomatic young patient with a Wolff-Parkinson-White (WPW, ventricular preexcitation) electrocardiographic pattern: developed in partnership between the pediatric and congenital electrophysi. Hear Rhythm 2012 Jun 1;9(6):1006-24.

https://doi.org/10.1016/j.hrthm.2012.03.050
20. La Rocca TJ, Beyersdorf GB, Li W, Foltz R, Patel AR, Tanel RE. Comparison of electrophysiologic profiles in pediatric patients with incidentally identified pre-excitation compared with Wolff-Parkinson-White syndrome. Am J Cardiol 2019;124(3):389-95.

https://doi.org/10.1016/j.amjcard.2019.04.053

21. Koca S, Pac FA, Kavurt AV, Cay S, Mihcioglu A, Aras D, et al. Transesophageal and invasive electrophysiologic evaluation in children with Wolff-Parkinson-White pattern. PACE - Pacing Clin Electrophysiol 2017;40(7):808-14.

https://doi.org/10.1111/pace. 13100

22. Bengali R, Wellens HJJ, Jiang Y. Perioperative management of the Wolff-Parkinson-White syndrome. Journal of Cardiothoracic and Vascular Anesthesia 2014;28:1375-86.

https://doi.org/10.1053/j.jvca.2014.02.003

23. Larson NP, Rosenthal JB, Bridwell RE, Tannenbaum L, Cibrario A. Hide and seek: intermittent preexcitation Wolff-ParkinsonWhite syndrome case report and management overview. Cureus 2020;12(7).

https://doi.org/10.7759/cureus.8971

24. Chubb H, Campbell RM, Motonaga KS, Ceresnak SR, Dubin AM. Management of asymptomatic Wolff-Parkinson-White pattern by pediatric electrophysiologists. J Pediatr 2019;213:8895.e1.

https://doi.org/10.1016/j.jpeds.2019.05.058

25. Page RL, Joglar JA, Caldwell MA, Calkins H, Conti JB, Deal $\mathrm{BJ}$, et al. $2015 \mathrm{ACC} / \mathrm{AHA} / \mathrm{HRS}$ guideline for the management of adult patients with supraventricular tachycardia: executive summary: a report of the American College of Cardiology/ American Heart Association task force on clinical practice guidelines and the heart rhythm. Circulation. Lippincott Williams and Wilkins 2016;133: e471-505. https://www.ahajournals.org/ doi/10.1161/CIR.0000000000000310

\section{WOLFF-PARKINSON-WHITE SYNDROME AND PATTERN \\ V. Zieniūtè, L. Daleckytė}

Keywords: Wolff-Parkinson-White syndrome, Wolff-Parkinson-White pattern, ventricular preexcitation syndrome, electrocardiography, Ebstein anomaly.

Summary

Wolff-Parkinson-White (WPW) syndrome - congenital electrical abnormality within the heart, being the most common reason to cause ventricular preexcitation. Patients with WPW syndrome have an additional electrical pathway, known as bundle of Kent, which conducts electrical impulses from the atria to the ventricles. Etiology is associated with mutation in the PRKAG2 gene. WPW syndrome may be a cause of life-threatening events, such as atrial fibrillation and sudden death. The diagnosis of WPW syndrome is usually determined by electrocardiography (ECG), which can show signs of ventricular preexcitation. Catheter ablation is indicated for symptomatic patients or patients with a high risk of sudden death.

Correspondence to: viktorijazieniute@gmail.com

Gauta 2020-11-14 